\title{
Possibility of Agritourism Development For Sustainable Rural Development In Sri Lanka
}

\author{
J.A PrasanshaKumari, \\ Senior Lecturer, Department of Economics, University of Kelaniya, Sri Lanka
}

\begin{abstract}
Agrtiturism is a growing industry in many parts of the world. At present, agritourism is promoted by most of the countries in the world aiming at sustainable rural development. This study intends to identify and analyze the potential for agritourism development in Sri Lanka with special reference to five farming areas in Kegalle district, Sri Lanka. SWOT analysis used to identify the possibility of agritourism in this areas. The study rival that there are several opportunities to development of agritourism while identified the main threat and weakness for developing agritourism in the study areas. The opportunities related to number of tourist attraction places and increase the demand for agritourism. Main problems related to infrastructure facilities, large farming lands, knowledge and skill of farmers, government support, credits and financial assistance, attitude of young generation and environmental impact.
\end{abstract}

Keywords:- agritourism, sustainable rural development, organic, farming.

\section{INTRODUCTION}

Agritourismis the process of attracting visitors to agricultural areas for educational and recreational purposes. Many developed and developing countries highly concern about development of agitourism as a sustainable rural development. According to Griver view of agritourism, it is a global trend which provides city dwellers an opportunity to escape from urban concrete environment and rediscover their roots in rural areas with farming [Griver, S. (2010)].The history of agritourism dates back to the late 1800's when people began leaving the city to come to farms to visit relatives for short stays to escape the city life [Hatch, A,D]. Recreation in rural areas is growing interest with the period of II world war and Great Depression in 1930 and 1940

There are growing interest among tourist for farm based activities such as buying produce direct from a farm stand, picking fruit and vegetables slopping hogs, feeding animals, or staying at a farm [Emily B (2007)]. Currently, agritourism industry have introduced many forms of activities to visitor, such as horseback riding, fee fishing, fee hunting, camping, nursery tours, wildlife viewing, petting zoo, skeet shooting, wagon ride, exotic farm animal, winery tours etc.[Hatch, A.D].

Agritourism sector is providing significant benefits to farmers and the whole rural economy. It provides opportunities to increase famer's supplemental income connecting with tourism activities as well as cash flows during off season. On the other hand, agritourism industry provide valuable opportunities to sell products grown and harvest from their farm lands. In addition it is providing opportunity to share the traditional knowledge and methods with different types of tourists.

\section{AGRICULTURE SECTOR IN SRI LANKA}

The Sri Lankan economy traditionally dominated by agriculture sector with more than $70 \%$ of the population living in rural areas depending on agriculture for their livelihoods. Currently this sector contributes to about $10.8 \%$ of the Gross Domestic Product (GDP)[ Sri Lanka socio economic data, 2014, CBSL] and 31.8\% of the total employment in the country.Rice is the main staple food in Sri Lanka cultivating 34 present from total farming land while 1.8 families engaging in paddy cultivation in the country. There are two cultivation seasons namely; Maha and Yala which are synonymous with two monsoons. According to Department of Census and Statistics Sri Lanka paddy harvest of 2.8 million MT in the Maha season2014/2015 [Department of Census and Statistics,2015]Coconut, Rubber Tea is main export plantation crop while earn high amount of foreign exchange from tea industry of the country. Sri Lanka export earnings from tea US\$1.6 billion in 2014[CBSL, 2014]. Fruits and vegetable are the important cultivation in the country. About 40 various varieties of vegetable and fruits gown in the different climate areas [EDB,2013]. Hill country usually cultivate appropriate vegetable and fruits for matching with cool temperate such as cabbagecarrot, beet, leek, cauliflower, salad leaves, bean, bell pepper and salad cucumber, grapes, strawberry. On the other hand law country trend to cultivate suitable variety of tropical fruits and vegetables for ideal to dry and wet climate such 
as red onion, pumpkin, green chili,, different varieties of banana, pineapple, papaya, mango, rambutan, guavas etc.

\section{AGRITOURISM IN SRI LANKA}

Sri Lanka is one of tourist attracted island in the world. There are many tourist attraction reasons and places in the country such as natural environment and wild life, coastal areas surrounding the country, popular Buddhist heritage places, and mountains, traditional and indigenous culture. On the other hand hospitality of Sri Lankan one of the important reason for attracting international visitors to the country. Currently tourism sector contributes to about $4.6 \%$ of the Gross Domestic Product while create direct and indirect job opportunity to local labor force [https://en.wikipedia.org]At present, agritourism sector in Sri Lanka is in a basic stage with provide initials facilities. Few tourist destinations engage with agritourism in all over the country. However Sri Lanka is a suitable tourist place since it has necessary basic requirement for developing agritourism such as different types of fruits, vegetables, crops, dairy farms different types of climate condition, cultural and religious activities, unique local foods and accommodation, etc. Moreover it is practicing traditional cultivation methods and organic farming in the agriculture sector as well as 2500 years old paddy cultivation system operate by using different type of traditional and hybrid rice varieties[Malkanthi,S.H.P\&Routry,J.K.(2011]. Currently, influencing global trend for agritourism, Sri Lankan government and tourist board concerning to promote agritourism sector in Sri Lankan context

\section{RESEARCH OBJECTIVES}

This study attempts to analyze the potential of agritourism development in the Sri Lankan rural agricultural sector as a tool of rural development

\section{RESEARCH METHODOLOGY}

The research data was done through a structured questionnaire which was administered to a randomly selected 200 farming family in rural agricultural areas of Kegalle and Rathnapura districts in Sri Lanka. Secondary data collected from books, magazine, annual reports and other relevant documents and wed sources. Only the selected sections of the survey data will be used the present paper. The data was analyzed using SOWT analysis

\section{DATA ANALYSIS AND RESULT}

Table I indicates the population distribution information in Rathnapura and Kegalle district by sector (rural, urban, estate)

Table IPopulation Distribution Information by Sector

\begin{tabular}{|l|r|l|l|l|}
\hline & $\begin{array}{l}\text { Total } \\
\text { Population }\end{array}$ & Urban & Rural & Estate \\
\hline Sri Lanka & $20,359,439$ & 18.2 & 77.4 & 4.4 \\
Sabaragamuwa & $1,928,655$ & 6.0 & 85.9 & 8.1 \\
Rathnapura & $1,088,007$ & 9.1 & 81.7 & 9.2 \\
Kegalle & 840,648 & 1.9 & 91.3 & 6.8 \\
& & & & \\
\hline
\end{tabular}

Source: Census of Population and Housing 2012, Sabaragamuwa Province.

As illustrated in Table I, 77.4 percent of total population living in rural areas in Sri Lanka. Rathnapura and Kegalle districts located in Samaragamuwa province. Majority of population of these districts are living in rural sector following by 81.7 present and 91.3[Department of Census and Statistics,2012] Both two districts cultivate various plantation crops and traditional agricultural crops such as tea, rubber, coconuts, cocoa, cinnamon and rice, vegetable, fruits etc. On the other hand, both district have valuable historical places, forest, river, natural park to get tourist attraction. Moreover, cultural and religious activities, unique local foods and accommodation will be helped to develop agritourism in both districts.

Table IIDemographic Characteristics

\begin{tabular}{|c|c|c|}
\hline Characteristics & Number of farmers & Percentage \\
\hline Crop & 54 & 27 \\
\hline Tea & 43 & 21.5 \\
\hline Rubber & 24 & 12 \\
\hline Coconut & 52 & 26 \\
\hline Paddy &
\end{tabular}




\begin{tabular}{|c|c|c|}
\hline Vegetable & 11 & 5.5 \\
\hline Fruits & 07 & 3.5 \\
\hline Other & 09 & 4.5 \\
\hline Total & 200 & 100 \\
\hline \multicolumn{3}{|c|}{ Age } \\
\hline $20-30$ & 15 & 7.5 \\
\hline $31-40$ & 26 & 13 \\
\hline $41-50$ & 58 & 29 \\
\hline $51-60$ & 61 & 30.5 \\
\hline $61-70$ & 22 & 11 \\
\hline 71 and above & 18 & 09 \\
\hline Total & 200 & 100 \\
\hline \multicolumn{3}{|c|}{ Size of farming land } \\
\hline$<1$ (acres) & 13 & 17.57 \\
\hline $1-2$ & 40 & 54.05 \\
\hline $2.1-3$ & 11 & 14.87 \\
\hline $3.1-4$ & 02 & 2.70 \\
\hline 4.1 and above & 03 & 4.05 \\
\hline \multicolumn{3}{|c|}{ Education } \\
\hline Non education & 21 & 10.5 \\
\hline $\mathrm{O} / \mathrm{L}$ & 77 & 38.5 \\
\hline $\mathrm{A} / \mathrm{L}$ & 59 & 29.5 \\
\hline First degree & 18 & 9 \\
\hline Postgraduate & 08 & 4 \\
\hline Other & 17 & 8.5 \\
\hline Total & 200 & 100 \\
\hline
\end{tabular}

As shown in Table II, 27 percent of the farmers cultivated tea crop while $26 \%$ farmers were cultivated paddy. 21.5 present famers were cultivated Rubber and 12 present engaged with coconuts cultivation. Farmers who cultivated vegetable and fruit crops were at $5.5 \%$ and $3.5 \%$ in both districts. Age groups show that oldest category (51-60) indicated the highest percentage with $30.5 \%$ of farming activities, while the percentage was $29 \%$ for the age group between 41-50 years. The second category was for the age group between 31-40 years projects a 13 percentage while the first age group between 20-30 years received the lowest percentage of 7.5. With regards to size of farming land, Table IV shows that 54.05 percentage of lands were between acers 1-2, while the 17.57 percentage lands were less 1 acres. 14.87 for 2.1-3 acres farming land, the smallest percentages goes to the farming land which was 3.1-4 acres at $2.70 \%$ and 4.1 and above acres with $4.05 \%$. Considering education, the highest percentage was $38.5 \%$ for farmers with the $\mathrm{O} / \mathrm{L}$ qualification, and the second highest category was for farmers with A/L qualification which was $29.5 \%$ of the sample. While for farmers' first degree and postgraduate qualification at less percentages they were 9. \%and 4\%. The study identified that 10.5 percentage of total sample did not attend to school education.

Figure I indicates the unemployment rate in farming community. 18 percent of farmers unemployed in age group of 31-40 while showing 10 percent unemployment rate from age category of 41-50. The highest rate of unemployment goes to age group of 61-70 at 19 percent

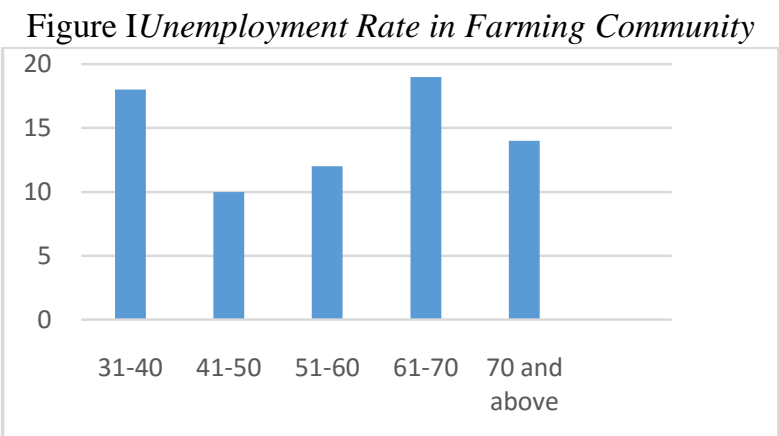




\section{SOWT Analyses for Potential of Agritourism}

Identify the potential of agritourism development in Sri Lanka, SWOT analyses can be used to find solution. Strength(S), Weakness(W), Opportunities $(\mathrm{O})$ and Threats(T) views as essential factors to develop the agritourism in the areas. When analyses using SOWT, Strength point should be concerned, the farmers cultivating different types of specific crops such as tea, rubber coconut, vegetable, fruits etc. Many of famers have own farm land and other agricultural requirement while traditional and organic farming activities highly using in the consumption level cultivation. The study identified that availability of family labor can be used to develop the agritourism. Oldest and middle ages farmers in the areas highly engaged with farming activities who have good knowledge about traditional and other farming activities. Many farmers had essential education qualification to train in agritourism sector with new farming activities. Concerning about tourist attraction, both district have beautiful natural landscape consisted of forest, mountain, natural park, river and clean natural environment provided high value for the area. Moreover, these areas rich in traditional and cultural activities such as religious ceremony, traditional dancing, music, traditional foods varieties to increase the tourist attraction. According to study, identified several weakness of potential for developing agritourism. Most of farm lands are small size and insufficient level in usage new equipment, hard to provide accommodation facilities to the visitors since over 74 present farming lands were below 2 acres in the area. Famers did not have enough knowledge about agritourism and its advantages. They had initial stage ability to creating new products andbusiness relating to agriculture. Less awareness of financial management, entrepreneurship ability, management and decision making ability, skill development ability had identified as weakness for initiating agritourism industry of these areas.

Main opportunities can be considered, study area can be used to develop the agritourism due to it has many tourist attraction activities such as adventure tourism, sport tourism and health tourism. In addition,the study identify that many of farming family had unemployed young family members that can be employed to agritourism industry. Due to the presence of nongovernmental organization and government concern to develop the traditional and organic farming industry will be used to more tourist attraction to the area.

Few threats of agritourism industry were identified. Less develop infrastructures facilities such as rural roads, water supply and electricity supply, communication facilities will be threats to agritourism. Insufficient government attention to development of rural agricultural sector, less credit flows and capital to the rural sector also identified as the main threats to initiatingagritourism industry. Table III presents the summary of SOWT analysis.

Strength $(S)$

Table IIISummary of SWOT Analysis

- Availability of different types of specific crops such as tea, rubber coconut, vegetable, fruits etc.

- Availability of own farming land and equipment

- $\quad$ Presence of traditional farming activities

- Availability of significant level of family labor

- Availability of sufficient number of knowledgeable and educated farmers

- Presence of beautiful natural landscape consisted of forest, mountain, Natural Park, river and clean natural environment provided high value for the area.

- Availability of traditional and cultural activities such as religious ceremony, traditional dancing, music, traditional foods varieties

Weakness (W)

- Farm lands are small size and insufficient level of usage new equipment

- Less develop infrastructures facilities such as rural roads, water supply and electricity supply, communication facilities

- Low awareness of agritourism and its benefits with farmers

- Poor level of financial management

- Less awareness of entrepreneurship ability, management and decision making ability Opportunities $(O)$

- Availability of many tourist attraction locations and activities such as adventure tourism, sport tourism and health tourism.

- Availability of unemployed young family members that can be employed to agritourism industry

- Initiation emphasis of nongovernmental organizations on develop of traditional and organic farming industry in areas

- Government concern of agritourism development is gradually increasing

Threats $(T)$

- Insufficiencies government attention to development of rural agricultural sector and solve the farmer's socio economics issues

- Urbanization of rural areas due to increasing population 
- Competition from other popular tourist destination

- Natural disaster and environment pollution

\section{CONCLUSION}

The both districts selected for the study have many potential for beginning agritourism industry which will be able to reach sustainable rural development. Many farmers had basic knowledge and equipment that are important to fulfill basic requirements of agritourism. Study area has many tourist attraction places. There are several important religious and cultural places which were almost used as tourist destinations. Moreover, the study has identified several opportunities and strengths to introduction the agritourism as unemployed labor force, traditional farming knowledge, organic cultivation methods

However, the area did not have enough infrastructure facilities to success of agritourism. Currently, agriculture sector have facing several problems which will be badly affected to agritourism development in the area. Although farmers had less management skills and entrepreneurship ability to create new industry. On the other hand there were few weakness and threats to develop the agritourism sector as less government attention, insufficient credit facilities.

\section{REFERANCES}

[1] Griver, S, (2010). Agricultural tourism, http:// from www.jewisvirtuallibrary.org/jsource/agriculture/agtour.html , downloaded on January 2016

[2] Hatch, A,D.Agri- tourism: A new Agricultural Business Enterprise, LSU Age Centre, http://www.caes.uga.edu/topics/sustainag/documents/LSUAgritourism_Pamphlet1.pdf).

[3] Emily B (2007). "Down on the Farm With Your Sleeves Rolled Up". New York Times. Retrieved 2009-0704.

[4] Department of Census and Statistics, Paddy Statistics, 2014/2015 Maha Season , ISBN 978-955-577-9661, N0 306/71, Polduwa road, Battharamulla

[5] Central Bank, Sri Lanka, Annual Report (2014) Retrieved Oct 30, 2015, fromhttp://www.cbsl.gov.lk/pics_n_docs/10_pub/_docs/efr/ annual report/AR2014/English/content.htm

[6] Export Development Board, Sri Lanka, Industry Capability Report(2013) Sri Lankan Fresh Fruit and Vegetable, from http://www.srilankabusiness.com/pdf/fruit_and_vegetable.pdf

[7] https://en.wikipedia.org/wiki/Agriculture_in_Sri_Lanka

[8] Malkanthi,S.H.P\&Routry,J.K.(2011) Potential for Agritourism Development: Evidence from Sri Lanka , The Journal of Agricultural Science, Vol. 6 No. 9.

[9] Highlights, census of population and housing 2012, Sabaragamuwa province,Department of Census and Statistics, Sri Lanka 